\title{
The Effect of Veneer Densification Temperature and Wood Species on the Plywood Properties Made from Alternate Layers of Densified and Non-Densified Veneers
}

\author{
Emilia-Adela Salca $^{1, *(\mathbb{D}}$, Pavlo Bekhta ${ }^{2, *}$ [C and Yaroslav Seblii ${ }^{2}$ \\ 1 Faculty of Wood Engineering, Transilvania University of Brasov, Eroilor 29, 500036 Brasov, Romania \\ 2 Department of Wood-Based Composites, Cellulose and Paper, Ukrainian National Forestry University, \\ Gen. Chuprynky 103, 79057 Lviv, Ukraine; yruk1996@gmail.com \\ * Correspondence: emilia.salca@unitbv.ro (E.-A.S.); bekhta@nltu.edu.ua (P.B.)
}

Received: 25 May 2020; Accepted: 23 June 2020; Published: 24 June 2020

\begin{abstract}
In this study the properties of plywood manufactured from densified and non-densified veneer sheets and alternate layers of such veneers with and without densification using low amount of adhesive as a function of densification temperature and wood species were investigated. The plywood panels were made from rotary-cut birch and black alder veneers using urea-formaldehyde (UF) adhesive. Veneer sheets with thickness of $1.5 \mathrm{~mm}$ were subjected to the thermal-compression at three different temperatures while keeping constant the pressure during a same time span. Five-layers plywood panels were produced using a constant hot-pressing schedule using different amounts of glue spread as a function of the plywood type; such as plywood made from non-densified $\left(80 \mathrm{~g} / \mathrm{m}^{2}\right)$ and densified $\left(60 \mathrm{~g} / \mathrm{m}^{2}\right)$ veneers only; and combination of them $\left(70 \mathrm{~g} / \mathrm{m}^{2}\right)$. The bending strength (MOR) and the modulus of elasticity (MOE) along with the shear strength of the plywood samples for bonding class 1 (dry conditions) have been determined. As expected bending strength of the plywood samples increased with the increasing in density. The increase of veneer densification temperature resulted in a gradually decrease of MOR; MOE and shear strength values for the plywood panels made of densified veneers and mixed panels of both species. The temperature of $150{ }^{\circ} \mathrm{C}$ for veneer densification seemed to be enough to achieve enhanced bending and bonding properties. All plywood panels in this study were manufactured using reduced glue consumption and they presented satisfactory properties performance for indoor applications.
\end{abstract}

Keywords: birch; black alder; densification; plywood properties

\section{Introduction}

Plywood has an attractive appearance of natural wood as compared to that of other wood-based composite panels. It is mostly used for furniture manufacturing and indoor design but also it can be used for interior and exterior building production [1,2]. The strength properties of the product along with its dimensional stability are required in such sectors. Several factors have major influence on the mechanical properties of plywood, especially on the bending strength (MOR) and modulus of elasticity (MOE), namely wood species, density, structure, moisture content, number of veneer layers, and type of adhesive and its spreading [2-7]. Various modification methods can be used to improve the properties of such products, the thermo-mechanical densification at elevated temperatures of solid wood is one of these methods [8-10].

It is also fact that plywood produced from compressed veneers sheets has enhanced properties [11,12]. The combination of heat and compression is an environmentally friendly method 
and influences overall the glue line strength of the final product [13]. But a special attention should be granted to the densification because an excessive process may cause negative effects, such as heavier plywood and higher dimensional changes in certain conditions and lower glue bond performance $[1,7]$. There is a high interest to manufacture environmentally friendly engineering products by using less adhesive spread rate [1]. Studies in this field showed that the veneer densification applied prior to plywood manufacturing reduced (by $40 \%$ ) the glue spread and pressure while the shear strength of the finished product was improved [14-16].

In previous studies, the veneers of one [14,16-19] or two thicknesses [1] were used in thermo-mechanical densification process to produce plywood mainly with non-densified or densified veneers, or with densified outer layers and non-densified core.

There is little or no information on the properties of plywood when manufactured from combinations of veneers with and without densification in one plywood structure. Therefore the aim of this work was to evaluate the effect of veneer densification temperature and wood species on the plywood properties made from alternate layers of densified and non-densified veneers. The combinations of densified and non-densified veneers within the same plywood structure are expected to generate value-added wood-based products.

\section{Materials and Methods}

Commercially manufactured rotary-cut veneers of birch (Betula verrucosa Ehrh.) and black alder (Alnus glutinosa L.) native in Ukraine were used for the experiments. The veneer sheets had a thickness of $1.5 \mathrm{~mm}$ and a moisture content of $7.4 \%$. A total of 140 veneer samples with dimensions of $300 \times 300 \mathrm{~mm}^{2}$ were prepared for the experiments.

\subsection{Veneer Densification}

The densification process of the veneers was performed under laboratory conditions. A constant pressure of $2 \mathrm{MPa}$ for $3 \mathrm{~min}$ time span was applied at three different temperature levels of $150{ }^{\circ} \mathrm{C}$, $180^{\circ} \mathrm{C}$ and $210^{\circ} \mathrm{C}$, respectively. The moisture content of densified veneer was of about $2.2 \%$.

\subsection{Plywood Preparation}

Five-layer plywood samples were manufactured from the two species under laboratory conditions. Three types of plywood from each species were produced by employing same press parameters including pressure, temperature and time. The glue spread varied as function of the plywood type made of non-densified veneers $(N)$, densified veneers $(D)$ and mixed $(M)$ as a combination of densified (d) and non-densified veneers (n) within the same structure (d-n-d-n-d) as it is displayed in Table 1.

Table 1. The pressing parameters for plywood manufacturing and plywood structures.

\begin{tabular}{|c|c|c|c|c|c|c|c|}
\hline \multirow{3}{*}{ Wood Species } & \multirow{3}{*}{$\begin{array}{c}\text { Type of Plywood per } \\
\text { Species }\end{array}$} & \multirow{3}{*}{\multicolumn{2}{|c|}{$\begin{array}{l}\text { Codification: } \\
\text { Densification } \\
\text { Temperature and } \\
\text { Plywood Symbol }\end{array}$}} & $\begin{array}{l}\text { Glue Spread, } \\
\mathrm{g} / \mathrm{m}^{2}\end{array}$ & $\begin{array}{l}\text { Pressure, } \\
\mathrm{MPa}\end{array}$ & $\begin{array}{l}\text { Temperature, } \\
{ }^{\circ} \mathrm{C}\end{array}$ & $\begin{array}{c}\text { Pressing } \\
\text { Time, s }\end{array}$ \\
\hline & & & & Variable & \multicolumn{3}{|c|}{ Constant Schedule } \\
\hline & & & & & 1.8 & 130 & $270+60$ \\
\hline \multirow{3}{*}{$\begin{array}{l}\text { Black alder/ } \\
\text { Birch }\end{array}$} & $\begin{array}{c}\text { Plywood made of } \\
\text { non-densified veneers }\end{array}$ & 0 & $\mathrm{~N}$ & 80 & \multirow[t]{3}{*}{ Bestor } & & \\
\hline & $\begin{array}{l}\text { Plywood made of } \\
\text { densified veneers and } \\
\text { densification } \\
\text { temperature }\end{array}$ & $\begin{array}{l}150 \\
180 \\
210\end{array}$ & $\mathrm{D}$ & 60 & & & \\
\hline & $\begin{array}{l}\text { Plywood made of } \\
\text { densified and } \\
\text { non-densified veneers } \\
\text { and densification } \\
\text { temperature }\end{array}$ & $\begin{array}{l}150 \\
180 \\
210\end{array}$ & M & 70 & & & \\
\hline
\end{tabular}


Usually in practice, under industrial conditions, the glue spread ranges from 110 to $150 \mathrm{~g} / \mathrm{m}^{2}$, as it is recommended by the adhesive producer. But in this study the adhesive ratios were reduced almost $50 \%$ of the recommended value. Two plywood panels were manufactured for each one of the plywood structure type.

The pressure was continuously reduced to $0 \mathrm{MPa}$ for the last $60 \mathrm{~s}$ of the pressing cycle. To manufacture the plywood a commercial urea-formaldehyde (UF) resin was used (specific gravity $=1.28 \mathrm{~g} / \mathrm{m}^{3}$, solid content $=65 \pm 2 \%, \mathrm{pH}=7.5 \pm 0.5$, viscosity $1000-2500 \mathrm{mPa} \mathrm{s}$ at $20{ }^{\circ} \mathrm{C}$ ). The adhesive was prepared using UF resin, caolin (as a filler), $20 \%$ solution of $\mathrm{NH}_{4} \mathrm{Cl}$ (as a hardener) and distilled water. The adhesive was manually applied onto one side of each uneven veneer sheet by using a roller. The veneers were perpendicularly oriented, layer by layer, in each plywood structure. Prior to any process step and test, both veneers with and without pre-treatment and the produced plywood structures were kept under constant room conditions at $20 \pm 2{ }^{\circ} \mathrm{C}$ and $65 \pm 5 \%$ relative humidity for a week.

\subsection{Density and Compression Ratio of the Plywood Samples}

The density of all types of plywood was determined according to EN 323 standard [20].

The compression ratio $\mathrm{CR}_{\mathrm{p}}$ of the plywood panels was calculated as shown below:

$$
\mathrm{CR}_{\mathrm{p}}=\left(\mathrm{T}_{\mathrm{v}}-\mathrm{T}_{\mathrm{p}}\right) / \mathrm{T}_{\mathrm{v}} \times 100(\%)
$$

in which $T_{v}$ is the total thickness of all veneers $(\mathrm{mm})$ and $T_{p}$ is the thickness of the panel.

\subsection{Bending Strength and Modulus of Elasticity of the Plywood Samples}

The bending strength (MOR) and the modulus of elasticity (MOE) have been determined according to EN 310 standard for each plywood type [21]. To test the mechanical properties the universal testing machine of SEIDNER type (Form + Test SEIDNER D-7940 Riedlingen West Germany) was used. The reported results of bending properties represent the average of ten samples for each plywood type.

\subsection{Shear Strength of the Plywood Samples}

The shear strength of the plywood samples was measured according to EN 314-1 [22] and EN 314-2 [23] standards for the plywood bonding class 1 (dry conditions). The samples were immersed in water at $20 \pm 3{ }^{\circ} \mathrm{C}$ for $24 \mathrm{~h}$. The reported shear strength data represent the average of 20 samples for each plywood batch type.

\subsection{Processing of Data}

All the data obtained in this study were statistically processed by employing the Minitab 17.3.1 software. Multifactorial ANOVA analysis of variance $(95 \% \mathrm{CI})$ for the mechanical properties and the response optimization between species for the best strength values of plywood samples were applied.

\section{Results and Discussions}

\subsection{Thickness, Compression Ratio, and Density of the Plywood Samples}

The density values along with the thickness and compression ratio of the plywood panels produced in this study are presented in Table 2. Based on the density differences between the two wood species, the density values for all the plywood categories made of birch veneers are higher than the values for black alder plywood panels. The values of plywood thickness for all types of panels were lower than the permissible values stipulated by EN 315 for thin veneers, in the range of 5.66-7.24 $\mathrm{mm}$ [24]. 
Table 2. Thickness, compression ratio, and density of the plywood samples.

\begin{tabular}{|c|c|c|c|c|c|c|c|c|}
\hline \multicolumn{2}{|c|}{$\begin{array}{c}\text { Densification Temperature and Type } \\
\text { of Plywood }\end{array}$} & $\begin{array}{c}\mathbf{0} \\
\mathbf{N}\end{array}$ & $\begin{array}{c}150 \\
D\end{array}$ & $\begin{array}{c}180 \\
D\end{array}$ & $\begin{array}{c}210 \\
D\end{array}$ & $\begin{array}{c}150 \\
M\end{array}$ & $\begin{array}{c}180 \\
M\end{array}$ & $\begin{array}{c}210 \\
M\end{array}$ \\
\hline \multirow{3}{*}{ Black alder } & Thickness, mm & $\begin{array}{c}6.98 \\
(0.18) *\end{array}$ & $\begin{array}{c}6.84 \\
(0.11)\end{array}$ & $\begin{array}{c}6.74 \\
(0.05)\end{array}$ & $\begin{array}{c}6.48 \\
(0.20)\end{array}$ & $\begin{array}{c}6.80 \\
(0.06)\end{array}$ & $\begin{array}{c}6.79 \\
(0.02)\end{array}$ & $\begin{array}{r}6.50 \\
(0.14)\end{array}$ \\
\hline & Compression ratio, $\%$ & 11.1 & 5.0 & 3.7 & 0.3 & 8.8 & 7.5 & 7.7 \\
\hline & Density, $\mathrm{kg} / \mathrm{m}^{3}$ & $\begin{array}{l}607.4 \\
(23.2)\end{array}$ & $\begin{array}{l}608.9 \\
(28.5)\end{array}$ & $\begin{array}{c}619.9 \\
(2.1)\end{array}$ & $\begin{array}{l}637.3 \\
(19.1)\end{array}$ & $\begin{array}{l}607.1 \\
(23.8)\end{array}$ & $\begin{array}{l}615.0 \\
(21.1)\end{array}$ & $\begin{array}{l}623.8 \\
(14.5)\end{array}$ \\
\hline \multirow{3}{*}{ Birch } & Thickness, mm & $\begin{array}{c}7.03 \\
(0.05)\end{array}$ & $\begin{array}{c}6.96 \\
(0.04)\end{array}$ & $\begin{array}{c}6.76 \\
(0.13)\end{array}$ & $\begin{array}{c}6.72 \\
(0.13)\end{array}$ & $\begin{array}{c}7.06 \\
(0.15)\end{array}$ & $\begin{array}{c}6.86 \\
(0.12)\end{array}$ & $\begin{array}{c}6.83 \\
(0.07)\end{array}$ \\
\hline & Compression ratio, $\%$ & 10.4 & 3.3 & 3.4 & 1.2 & 5.4 & 6.5 & 5.4 \\
\hline & Density, $\mathrm{kg} / \mathrm{m}^{3}$ & $\begin{array}{l}747.0 \\
(20.5)\end{array}$ & $\begin{array}{l}807.9 \\
(6.4)\end{array}$ & $\begin{array}{l}809.3 \\
(13.8)\end{array}$ & $\begin{array}{c}828.2 \\
(7.1)\end{array}$ & $\begin{array}{l}766.8 \\
(4.7)\end{array}$ & $\begin{array}{l}769.8 \\
(31.1)\end{array}$ & $\begin{array}{l}805.3 \\
(27.4)\end{array}$ \\
\hline
\end{tabular}

* numbers in parenthesis are standard deviations values.

\subsection{Bending Properties of the Plywod Samples}

The bending strength and the modulus of elasticity presented higher average values for birch plywood compared to black alder plywood for each one of the panel structures under study. Interval plots for $95 \%$ CI for the mean values of the MOR and MOE for all the plywood structures are displayed in Figures 1 and 2, respectively. As it was expected with increasing density the values of MOR and MOE of the plywood samples increased (Figure 3).

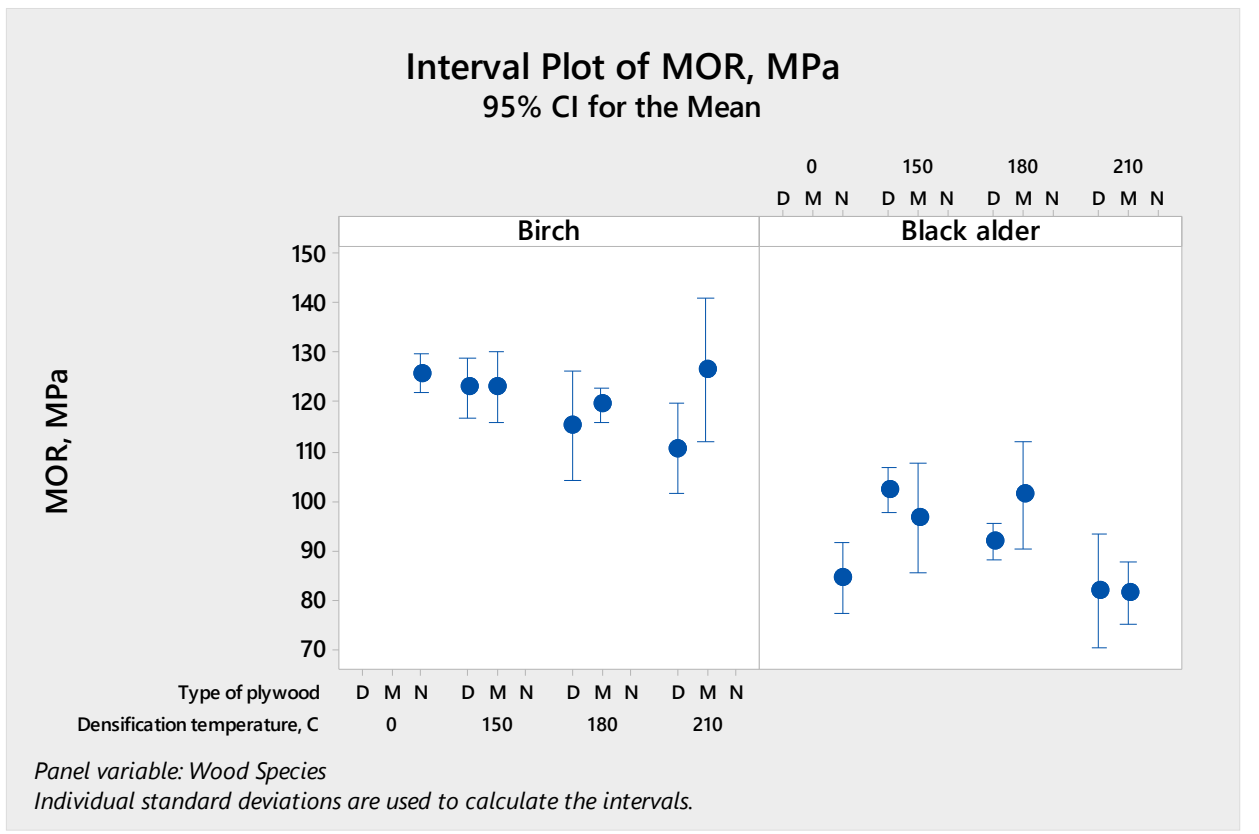

Figure 1. Variation of the bending strength (MOR) of birch and black alder plywood as a function of densification temperature of veneers prior to plywood manufacturing and the type of plywood: Made of densified (D), non-densified (N), and mixed (M) veneers. 


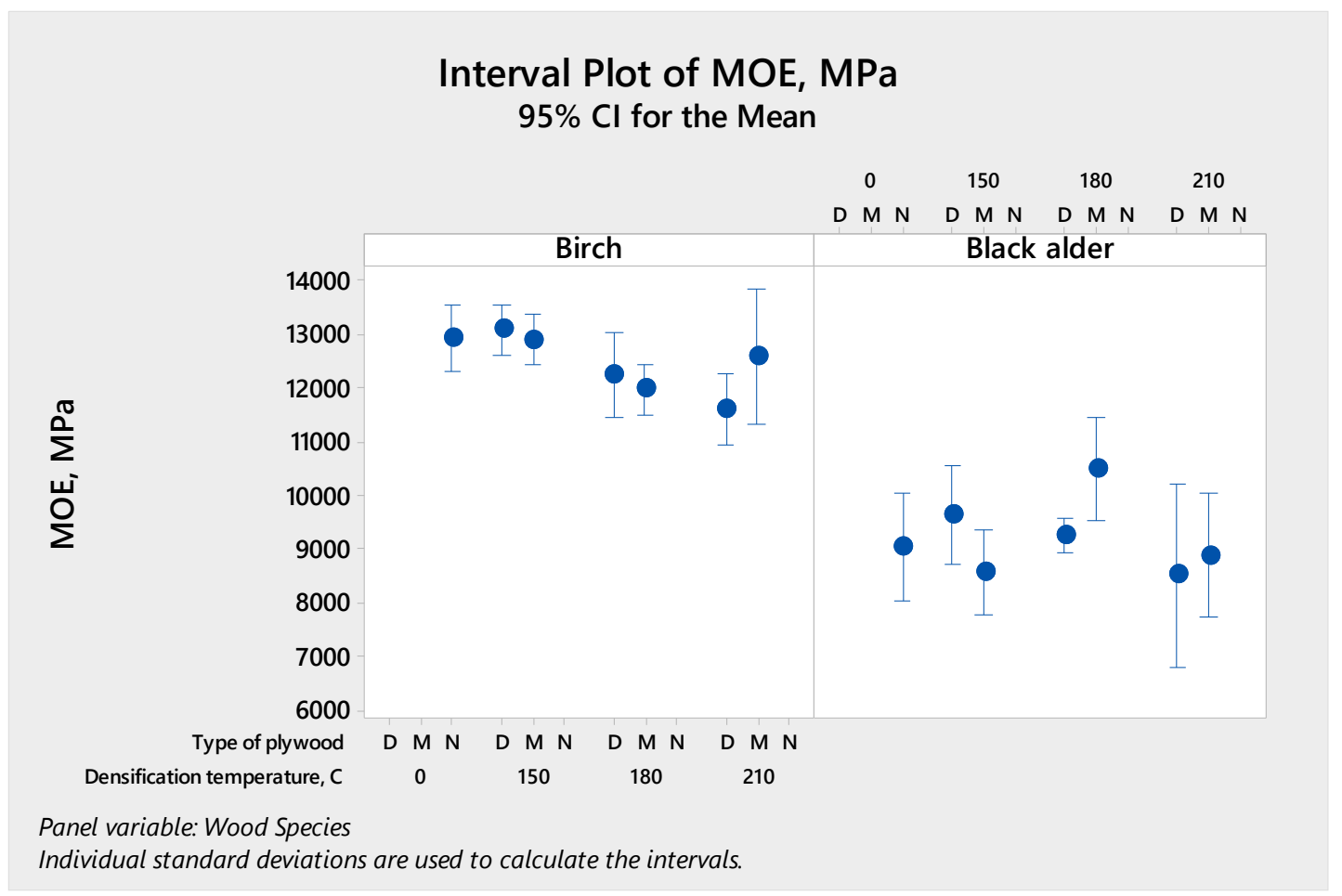

Figure 2. Variation of the modulus of elasticity (MOE) of birch and black alder as a function of densification temperature of veneers prior to plywood manufacturing and the type of plywood: Made of densified (D), non-densified (N), and mixed (M) veneers.

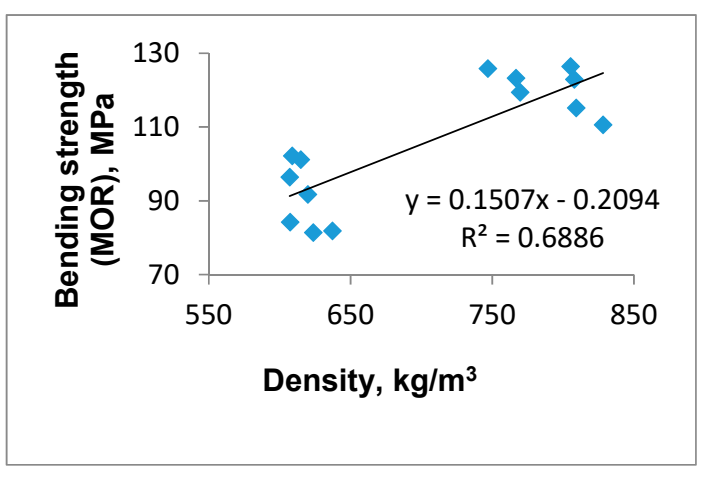

(a)

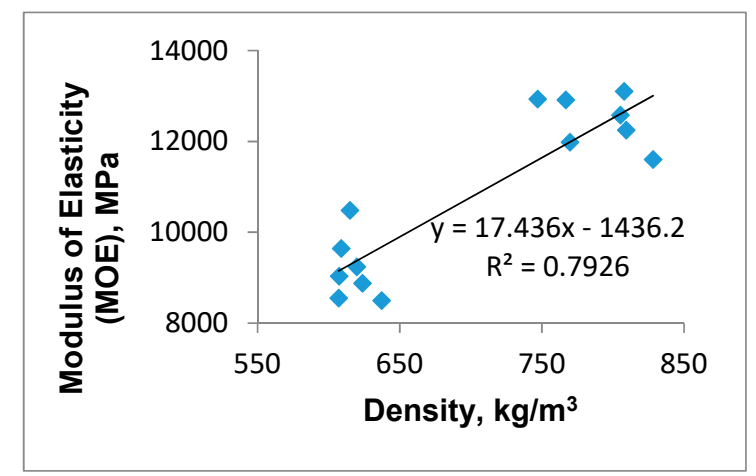

(b)

Figure 3. Relationship between the bending strength (MOR) - (a), modulus of elasticity (MOE)—(b) and density of plywood panels.

The birch plywood $\mathrm{N}$ had higher average values of MOR and MOE compared to all other average values obtained for the birch panels $\mathrm{D}$ made of densified veneers. A peak value for MOE of about 13,105 MPa was determined for the birch plywood at the temperature densification level of $150{ }^{\circ} \mathrm{C}$. It appears that the densification applied to birch veneers before plywood manufacturing did not show any essential enhancement in terms of panel bending properties.

Similar trends were found by Bekhta et al. for beech plywood samples [1]. The MOR values of beech plywood made of non-densified veneers presented higher values by an average of $8.2 \%$ for the panels made of thicker veneer and by $16.4 \%$ for the panels with thinner veneer when compared to the results for beech plywood made of non-densified veneers. The veneers undergo two times a densification, once during the specific densification process and later in the process of plywood manufacturing, which produced the weakening of bending strength. 
The adhesive spread, even almost 50\% lower than the amount used in industry, did not show much difference between the bending properties of the birch plywood panels made of densified veneers or combinations of veneers with and without densification.

But in the case of black alder plywood the MOR and MOE values were higher for panels made of densified veneers glued using a low glue spread of $60 \mathrm{~g} / \mathrm{m}^{2}$ than the ones of control non-densified veneers glued with a spread amount of $80 \mathrm{~g} / \mathrm{m}^{2}$.

For black alder plywood the densification process applied to veneers at the temperature levels of $150{ }^{\circ} \mathrm{C}$ and $180{ }^{\circ} \mathrm{C}$ resulted in increased values with $21.42 \%$ and $9.19 \%$ for MOR, and $6.75 \%$ and $2.28 \%$ for MOE, when they are compared to control panel $\mathrm{N}$, respectively.

Results of the samples determined in this study are comparable to those found in previous studies. Bekhta et al. found a MOR value of 123.8 MPa for 5-ply birch plywood made of densified veneers with cold-press using the PF adhesive at a glue spread of $135 \mathrm{~g} / \mathrm{m}^{2}$ [11]. When using the same PF adhesive at a higher spread of $160 \mathrm{~g} / \mathrm{m}^{2}$ for the birch plywood made of densified veneers a MOR value of $161 \mathrm{MPa}$ and a MOE value of 14,883 MPa were found [25]. In the case of black alder plywood made of densified veneers glued with UF adhesive at a spread rate of $160 \mathrm{~g} / \mathrm{m}^{2}$ a higher MOR value of $119.8 \mathrm{MPa}$ when compared to the results of the present study was achieved [26].

The results of bending properties showed that the increase of veneer densification temperature resulted in a gradually decrease of MOR and MOE values for the plywood panels made of densified veneers of both species. The same trend was noticed for almost all mixed panels.

For birch plywood only small differences were noticed between the MOR and MOE values of plywood panels D compared to $\mathrm{M}$ for the temperature levels of veneer densification of $150{ }^{\circ} \mathrm{C}$ and $180{ }^{\circ} \mathrm{C}$. Thus, a slight and gradual increase of about $0.08 \%, 3.47 \%$, and $14.54 \%$ in MOR values was noticed for panels $\mathrm{M}$ compared to panel $\mathrm{D}$ at the same temperature level of veneer densification, increasing from $150^{\circ} \mathrm{C}$ to $180^{\circ} \mathrm{C}$, and then to $210^{\circ} \mathrm{C}$, respectively. The highest increase of $8.42 \%$ for the MOE value of the birch panels M from D was found at the temperature densification level of $210^{\circ} \mathrm{C}$.

For black alder plywood panels D compared to $\mathrm{M}$, the MOR and MOE values subsequently decreased and increased with slow rates for different temperature levels of veneer densification. Thus, given the temperature densification level of $150^{\circ} \mathrm{C}$ of black alder veneers, the MOR value for panel M was $5.88 \%$ lower than the one for panel D.

But the MOR and MOE values increased with $10.98 \%$ and $13.45 \%$ from panel $\mathrm{D}$ to panel $\mathrm{M}$ at the temperature densification level of $180{ }^{\circ} \mathrm{C}$, respectively. No relevant changes were determined for the black alder panels $\mathrm{M}$ and $\mathrm{D}$ at the veneer densification level of $210^{\circ} \mathrm{C}$.

The highest MOE value of 10,482 MPa was determined for black alder mixed panel $\mathrm{M}$ at the veneer densification level of $180^{\circ} \mathrm{C}$.

The strength values are significantly affected by the density of the samples. Overall, very low differences in densities and bending properties have been noticed for plywood panels $\mathrm{D}$ and $\mathrm{M}$ for both species under study. The outer densified layer is responsible for the bending strength. In a previous study for mixed plywood panels made of densified and non-densified beech veneers a decrease in MOR values when compared to panels made of densified veneers was found [1]. The values for bending strength and modulus of elasticity obtained for all the plywood structures were found higher than the limit values for structural plywood panels.

\subsection{Shear Strength of the Plywood Samples}

The shear strength mean values of all plywood panels were above the limit of $1 \mathrm{MPa}$ indicated by the EN 314-2 [23]. All plywood panels manufactured in this study presented satisfactory bonding value for indoor applications (Figure 4).

The mean shear strength value of the birch panels made of non-densified veneers N (2.40 MPa) was found lower than that one for black alder control panels (2.98 MPa).

As regards to the other two types of panels, $\mathrm{D}$ and $\mathrm{M}$, the shear strength values were found higher for birch plywood than for black alder plywood when considering the same plywood structure type. 


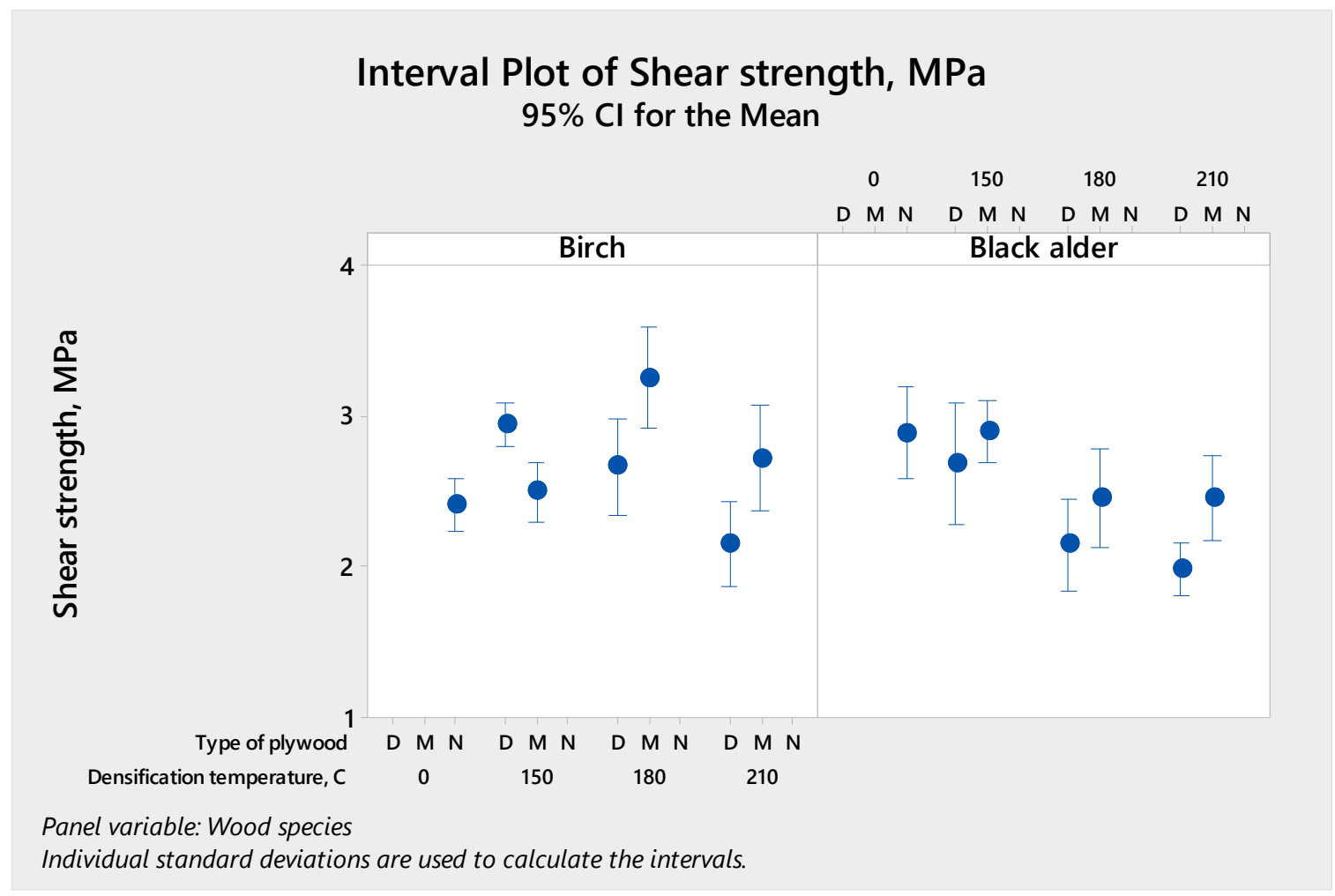

Figure 4. Variation of the shear strength of birch and black alder plywood as a function of densification temperature of veneers prior to plywood manufacturing and the type of plywood: Made of densified (D), non-densified $(\mathrm{N})$, and mixed $(\mathrm{M})$ veneers.

In the case of birch plywood D, the densification of veneers applied prior plywood manufacturing produced an enhancement of the bonding quality with $22.9 \%$ and $10.83 \%$ for the panels made of densified veneers at the temperature level of $150{ }^{\circ} \mathrm{C}$ and $180{ }^{\circ} \mathrm{C}$, while the temperature level of densification at $210^{\circ} \mathrm{C}$ did not show a better shear strength compared to birch control panel $\mathrm{N}$. The highest mean value for the shear strength of panels D of about 2.95 MPa was obtained for panels at the densification temperature level of $150^{\circ} \mathrm{C}$.

Such results are in accordance with those found in the specialty literature. The densification of veneers produces a smoother surface that was proved to enhance the shear strength of plywood samples [26]. It was also proved that the adhesive spread for such smooth veneers should be lower than for the non-densified veneers and the final product can meet the standard requirements for plywood panels $[1,26]$. This statement applies to the present study as well.

In a previous work the shear strength increased from 0.77 to $3.22 \mathrm{MPa}$ for beech plywood produced from densified veneers with a UF glue spread of $110 \mathrm{~g} / \mathrm{m}^{2}$ when compared to plywood of non-densified veneers, while for a higher glue spread of $180 \mathrm{~g} / \mathrm{m}^{2}$, only a small increase of $12.69 \%$ was determined [1].

In terms of shear strength, values in the same range with the results in this work for birch plywood, but with higher glue spread rates than the ones used in the current study, can be found in the literature [11,25-27].

In the case of black alder plywood made of densified veneers no improvement in terms of shear strength quality compared to the results for control panels was noticed.

The highest mean value for the shear strength of 2.89 MPa was obtained for panels of non-densified veneers $\mathrm{N}$ and mixed panels $\mathrm{M}$ at the densification temperature level of $150^{\circ} \mathrm{C}$.

Overall, the shear strength values presented little differences between panels $\mathrm{M}$ and $\mathrm{D}$ for both species, in most of the cases $\mathrm{M}$ was higher than $\mathrm{D}$. An exception was found in the case of birch panels $\mathrm{M}$ that had a lower shear strength value $(2.49 \mathrm{MPa})$ compared to that one of panels $\mathrm{D}(2.95 \mathrm{MPa})$ at the same densification temperature level of $150^{\circ} \mathrm{C}$. 
It appears that the better bonding strength of samples with mixed structure $\mathrm{M}$ when compared to panels $\mathrm{D}$ is due to the core (n-d-n) that acts like a compact adhesive layer. The higher glue spread of $70 \mathrm{~g} / \mathrm{m}^{2}$ compared to the one in panels $\mathrm{D}\left(60 \mathrm{~g} / \mathrm{m}^{2}\right)$ gives a good bonding to the outer densified layers.

The shear strength values gradually decreased with the increase of temperature level for veneer densification.

Increased rates of $25.3 \%$ and $26.51 \%$ of the shear strength values for birch panels $\mathrm{M}$ compared to $\mathrm{D}$ at the densification temperature levels of $180^{\circ} \mathrm{C}$ and $210^{\circ} \mathrm{C}$, respectively, were found. In the case of black alder gradually increased rates of about $7.83 \%, 14.48 \%$, and $24.24 \%$ of the bonding quality of panels $\mathrm{M}$ compared to $\mathrm{D}$ at the densification temperature levels of $150{ }^{\circ} \mathrm{C}, 180{ }^{\circ} \mathrm{C}$, and $210{ }^{\circ} \mathrm{C}$, respectively, were determined.

The highest mean value for the shear strength of mixed birch panels of about 3.26 MPa was found for panels $\mathrm{M}$ at the densification temperature level of $180^{\circ} \mathrm{C}$, while for black alder plywood the highest mean value was of about $2.89 \mathrm{MPa}$ for control panels $\mathrm{N}$.

\subsection{ANOVA Analysis and Response Optimization}

Multifactorial ANOVA analysis (Table 3) was applied to determine in what extent the mechanical properties of plywood panels were influenced by the wood species, densification temperature applied to veneer before plywood manufacturing and the type of plywood produced and pairs of these factors as well. The analysis showed that the wood species and densification temperature along with their interactive cumulative effect could be considered statistically meaningful for the strength properties ( $p$-value $\leq 0.05)$, while the type of plywood presented less significance. The test statistics showed that the densification temperature was found significant for MOR at $90 \% \mathrm{CI}(p$-value $\leq 0.1)$. The results showed that the wood species is not a statistically significant factor for the shear strength. Such results are in accordance with the statements previously presented and discussed in this work.

Table 3. Multifactorial ANOVA analysis of variance for the mechanical properties (Wood species = A; Densification temperature $=\mathrm{B}$ ).

\begin{tabular}{|c|c|c|c|c|c|c|}
\hline $\begin{array}{c}\text { One-Way ANOVA } \\
\text { Response }\end{array}$ & Source & $\begin{array}{c}\text { Degrees of } \\
\text { Freedom (DF) }\end{array}$ & $\begin{array}{l}\text { Adjusted Sums of } \\
\text { Squares (Adj SS) }\end{array}$ & $\begin{array}{c}\text { Adjusted Means } \\
\text { Squares (Adj MS) }\end{array}$ & F-Value & $p$-Value \\
\hline \multirow{3}{*}{$\begin{array}{l}\text { Bending strength } \\
\text { (MOR), } \mathrm{MPa}\end{array}$} & A & 1 & 30,315 & $30,314.7$ & 199.16 & 0.000 \\
\hline & B & 3 & 2538 & 846.1 & 5.56 & 0.001 \\
\hline & $A * B$ & 3 & 2361 & 787.0 & 5.17 & 0.002 \\
\hline \multirow{3}{*}{$\begin{array}{c}\text { Modulus of } \\
\text { elasticity (MOE), } \\
\mathrm{MPa}\end{array}$} & $\mathrm{A}$ & 1 & $363,249,244$ & $363,249,244$ & 213.91 & 0.000 \\
\hline & B & 3 & $11,208,650$ & $3,736,217$ & 2.20 & 0.091 \\
\hline & $A * B$ & 3 & $16,538,180$ & $5,512,727$ & 3.25 & 0.024 \\
\hline \multirow{3}{*}{$\begin{array}{l}\text { Shear strength (SS), } \\
\mathrm{MPa}\end{array}$} & $\mathrm{A}$ & 1 & 0.427 & 0.4272 & 1.05 & 0.306 \\
\hline & B & 3 & 7.929 & 2.6431 & 6.52 & 0.000 \\
\hline & $A * B$ & 3 & 10.358 & 3.4526 & 8.52 & 0.000 \\
\hline
\end{tabular}

In order to get the best plywood performance the manufacturing parameters need optimization. Based on the results of this study it appears that for both species the densification of veneers applied at $150{ }^{\circ} \mathrm{C}$ provides the best results in terms of bending properties and a good bonding quality of the plywood panels type $\mathrm{D}$ and $\mathrm{M}$; such properties have been achieved using a low glue consumption of about 60 and $80 \mathrm{~g} / \mathrm{m}^{2}$, respectively. No other temperature level higher than $150{ }^{\circ} \mathrm{C}$ is needed for veneers densification prior to plywood manufacturing.

Table 4 presents the response optimization when selected between species to obtain the best values predicted for the bending properties (MOR and MOE) and the shear strength of the plywood panels. The result shows that the mixed birch panels made of non-densified and densified veneers at the temperature level of $154.28{ }^{\circ} \mathrm{C}$ were found to have the best values of their bending and bonding properties. 
Table 4. Response optimization between species for the maximum strength values of plywood samples.

\begin{tabular}{|c|c|c|c|c|c|c|}
\hline Solution & $\begin{array}{c}\text { Densification } \\
\text { Temperature, }^{\circ} \mathrm{C}\end{array}$ & $\begin{array}{l}\text { Wood } \\
\text { Species }\end{array}$ & $\begin{array}{l}\text { Type of } \\
\text { Plywood }\end{array}$ & Properties & & $\begin{array}{l}\text { Composite } \\
\text { Desirability }\end{array}$ \\
\hline \multirow{3}{*}{1} & \multirow{3}{*}{154.286} & \multirow{3}{*}{ Birch } & \multirow{3}{*}{ M } & MOE, Mpa Fit & $12,830.8$ & \multirow{2}{*}{0.765479} \\
\hline & & & & MOR, Mpa Fit & 127.384 & \\
\hline & & & & Shear strength, Mpa Fit & 2.97644 & 0.569985 \\
\hline
\end{tabular}

\section{Conclusions}

In this study the effect of veneer densification temperature and wood species on the plywood properties when manufactured from non-densified, densified and from alternate layers of densified and non-densified veneers has been analyzed.

- The bending strength and the modulus of elasticity along with overall shear strength presented higher values for birch plywood compared to black alder plywood. They increased with the increasing in density.

- The densification applied to birch veneers compared to black alder presented little improvement in terms of panel bending properties but quite significant enhancement of the bonding quality. The densification of black alder veneer did not provide any improvement in terms of shear strength quality of the plywood panels.

- The increase of veneer densification temperature resulted in a gradually decrease of MOR, MOE, and shear strength values for the plywood panels made of densified veneers and mixed panels of both species. The temperature of about $150{ }^{\circ} \mathrm{C}$ for veneer densification seemed to be enough to provide the best values for bending and bonding properties of such panels.

- All plywood panels in this study were manufactured using reduced glue consumption and they presented satisfactory properties performance for indoor applications. Apart of the plywood properties performance, such an approach can provide low emissions of toxic compounds and low costs for the finished product.

- In further studies it would be desirable to evaluate some of the other properties of such samples including thickness swelling and water absorption would help better understanding behavior of these panels. Also some data on surface quality evaluation of non-densified and densified veneer sheets could help to optimize overall adhesive consumption.

Author Contributions: Conceptualization, methodology, software, validation, formal analysis, P.B., E.-A.S. and Y.S.; investigation, resources, and data curation, P.B. and E.-A.S.; writing-original draft preparation, E.-A.S.; writing-review and editing, E.-A.S. and P.B.; visualization and supervision, P.B.; supervision, P.B. All authors have read and agreed to the published version of the manuscript.

Funding: Part of this research was funded by the COST Action FP1407/STSM 41745.

Acknowledgments: We would like to thank for the support offered by the Laboratory of Wood-Based Composites, Cellulose \& Paper from the Ukrainian National Forestry University to perform this research.

Conflicts of Interest: The authors declare no conflict of interest.

\section{References}

1. Bekhta, P.; Salca, E.A.; Lunguleasa, A. Some properties of plywood panels manufactured from combinations of thermally densified and non-densified veneers of different thickness in one structure. J. Build. Eng. 2020, 29, 101116. [CrossRef]

2. Daoui, A.; Descamps, C.; Marchal, R.; Zerizer, A. Influence of veneer quality on beech LVL mechanical properties. Maderas Cienc Tecnol. 2011, 13, 69-83. [CrossRef]

3. Del Menezzi, C.; Mendes, L.; de Souza, M.; Bortoletto, G. Effect of Nondestructive Evaluation of Veneers on the Properties of Laminated Veneer Lumber (LVL) from a Tropical Species. Forests 2013, 4, $270-278$. [CrossRef] 
4. de Melo, R.R.; Del Menezzi, C.H.S. Influence of veneer thickness on the properties of LVL from Parica (Schizolobium amazonicum) plantation trees. Eur. J. Wood Wood Prod. 2014, 72, 191-198. [CrossRef]

5. Pałubicki, B.; Marchal, R.; Butaud, J.-C.; Denaud, L.-E.; Bléron, L.; Collet, R.; Kowaluk, G. A method of lathe checks measurement; SMOF device and its software. Eur. J. Wood Wood Prod. 2010, 68, 151-159. [CrossRef]

6. DeVallance, D.B.; Funck, J.W.; Reeb, J.E. Douglas-Fir plywood gluebond quality as influenced by veneer roughness, lathe checks, and annual ring characteristics. Forest Prod. J. 2007, 57, 21-28.

7. Wang, B.J.; Ellis, S.; Dai, C. Veneer surface roughness and compressibility pertaining to plywood/LVL manufacturing. Part II. Optimum panel densification. Wood Fiber Sci. 2006, 38, 727-735.

8. Seborg, R.M.; Millet, M.; Stamm, A.J. Heat-stabilized compressed wood. Staypack. Mech. Eng. 1945, 67, $25-31$.

9. Morsing, N. Densification of Wood. The Influence of Hygrothermal Treatment on Compression of Beech Perpendicular to the Grain. Ph.D. Thesis, Building Materials Laboratory, Technical University of Denmark, Lyngby, Denmark, 1997.

10. Navi, P.; Sandberg, D. Thermo-Hydro-Mechanical Wood Processing. Lausanne; EPFL Press: Lausanne, Switzerland, 2012.

11. Bekhta, P.; Hiziroglu, S.; Shepelyuk, O. Properties of plywood manufactured from compressed veneer as building material. Mater. Des. 2009, 30,947-953. [CrossRef]

12. Kutnar, A.; Kamke, F.A.; Sernek, M. Density profile and morphology of viscoelastic thermal compressed wood. Wood Sci. Technol. 2009, 43, 57-68. [CrossRef]

13. Arruda, L.M.; Menezzi, H.S.C. Properties of a laminated wood composite produced with thermomechanically treated veneers. Adv. Mater. Sci. Eng. 2016, 9. [CrossRef]

14. Bekhta, P.; Niemz, P.; Sedliacik, J. Effect of pre-pressing of veneer on the glueability and properties of veneer-based products. Eur. J. Wood Wood Prod. 2012, 70, 99-106. [CrossRef]

15. Bekhta, P.; Salca, E.A. Influence of veneer densification on the shear strength and temperature behavior inside the plywood during hot press. Constr. Build. Mater. 2018, 162, 20-26. [CrossRef]

16. Bekhta, P.; Sedliacik, J.; Jones, D. Effect of short-term thermomechanical densification of wood veneers on the properties of birch plywood. Eur. J. Wood Wood Prod. 2018, 76, 549-562. [CrossRef]

17. Candan, Z.; Hiziroglu, S.; Mcdonald, A.G. Surface quality of thermally compressed Douglas fir veneer. Mater. Des. 2010, 31, 3574-3577. [CrossRef]

18. Diouf, P.N.; Stevanovic, T.; Cloutier, A.; Fang, C.-H.; Blanchet, P.; Koubaa, A.; Mariotti, N. Effects of thermo-hygro-mechanical densification on the surface characteristics of trembling aspen and hybrid poplar wood veneers. Appl. Surf. Sci. 2011, 257, 3558-3564. [CrossRef]

19. Li, W.; Wang, C.; Zhang, Y.; Jia, C.; Gao, C.; Jin, J. The influence of hot compression on the surface characteristics of poplar veneer. BioRes 2014, 9, 2808-2823. [CrossRef]

20. EN 323. Wood-Based Panels_Determination of Density; European Committee for Standardization: Brussels, Belgium, 1993.

21. EN 310. Wood-Based Panels—Determination of Modulus of Elasticity in Bending and of Bending Strength; European Committee for Standartiztion: Brussels, Belgium, 1993.

22. EN 314-1. Plywood-Bonding Quality_Part 1: Test Methods; European Committee for Standardization: Brussels, Belgium, 2004.

23. EN 314-2. Plywood-Bonding Quality_Part 2: Requirements; European Committee for Standardization: Brussels, Belgium, 1993.

24. EN 315. Plywood. Tolerances for Dimensions; European Committee for Standardization: Brussels, Belgium, 2000.

25. Bekhta, P.; Sedliacik, J.; Bekhta, N. Effects of selected parameters on the bonding quality and temperature evolution inside plywood during pressing. Polymers 2020, 12, 1035. [CrossRef] [PubMed]

26. Bekhta, P.; Sedliacik, J. Environmetally-friendly high-density polyethylene-bonded plywood panels. Polymers 2019, 11, 1166. [CrossRef] [PubMed]

27. Bekhta, P.; Marutzky, R. Reduction of glue consumption in the plywood production by using previously compressed veneer. Holz Roh Werkst 2007, 65, 87-88. [CrossRef]

(C) 2020 by the authors. Licensee MDPI, Basel, Switzerland. This article is an open access article distributed under the terms and conditions of the Creative Commons Attribution (CC BY) license (http://creativecommons.org/licenses/by/4.0/). 